all corners. These disks were then copied successfully.

The dripping wet disks were peeled out of their plastic sleeves (see Figure 2). The plastic sleeves of some were relatively easy to pop open. Others were more difficult, and a paper cutter was used, first making sure to tap the sleeve to position the disk away from the edge being cut.

Each disk was then wiped dry with a rag! The janitor closet yielded a box of clean, soft, lint-free rags (from old thermal underwear). The waffleweave cloth shown in Figure 2 dried well and did not leave lint on the disks.

The disks were then hung for further air drying on the cataloging department "Easter egg tree" (Figure 3). This procedure kept the disks from touching each other, and also kept the disk surfaces from coming into contact with any other material or contaminants.

A new dry disk was then cut open by trimming off about $1 / 16$ inch of the write-protect edge with a paper cutter. The disk was removed from the plastic cover and set aside for later replacement. One by one the bare disks were slipped into this dry cover, run, and copied. All disks copied successfully, and everything - including the entire microsoftware serial — was salvaged.

\title{
Library consultant in Indonesia
}

\author{
By Tanja Lorkovic \\ Head of Cataloging \\ University of Iowa
}

\section{The state of librarianship in one developing country.}

\section{T} his article was inspired by the consulting report, "The Team Approach to Library Consulting in a Developing Country," by Carolyn A. Snyder, Larry W. Griffin, Andrea Singer, and Roger Beckman of the Indiana University Libraries $(C \& R L$ News, December 1985, pp. 629-32). It prompted me to recount my own experiences as a University of Iowa librarian during a year of consulting internationally at the University of North Sumatra, Medan, Indonesia.

In July 1984 the Office of International Education and Services of the University of Iowa announced that the Midwest Universities Consortium for International Activities (MUCIA) had been awarded a contract funded by the Asian Development Bank (ADB Loan No. 525-INO) for the University of North Sumatra/Universitas Sumatera Utara (USU) Development Project.
The project's objectives were to upgrade academic programs, curriculum, teaching management, library service, and physical facilities of USU. Among the four long-term and 21 short-term consultancies in diverse academic and professional fields was a request for a library specialist. I applied and in September 1984 I was appointed by MUCIA to the position of library specialist for the University of North Sumatra Project. In April 1985 the Project Implementation Unit at USU accepted my appointment. During the negotiation between that Unit and MUCIA, the initial 15 man-months for the library specialist was shortened to 12 manmonths with the provision that the remaining three months would be allocated for a specialized library consultation that might be needed later. The orientation process started at the University of Iowa where I was given a Bahasa Indonesia textbook, 


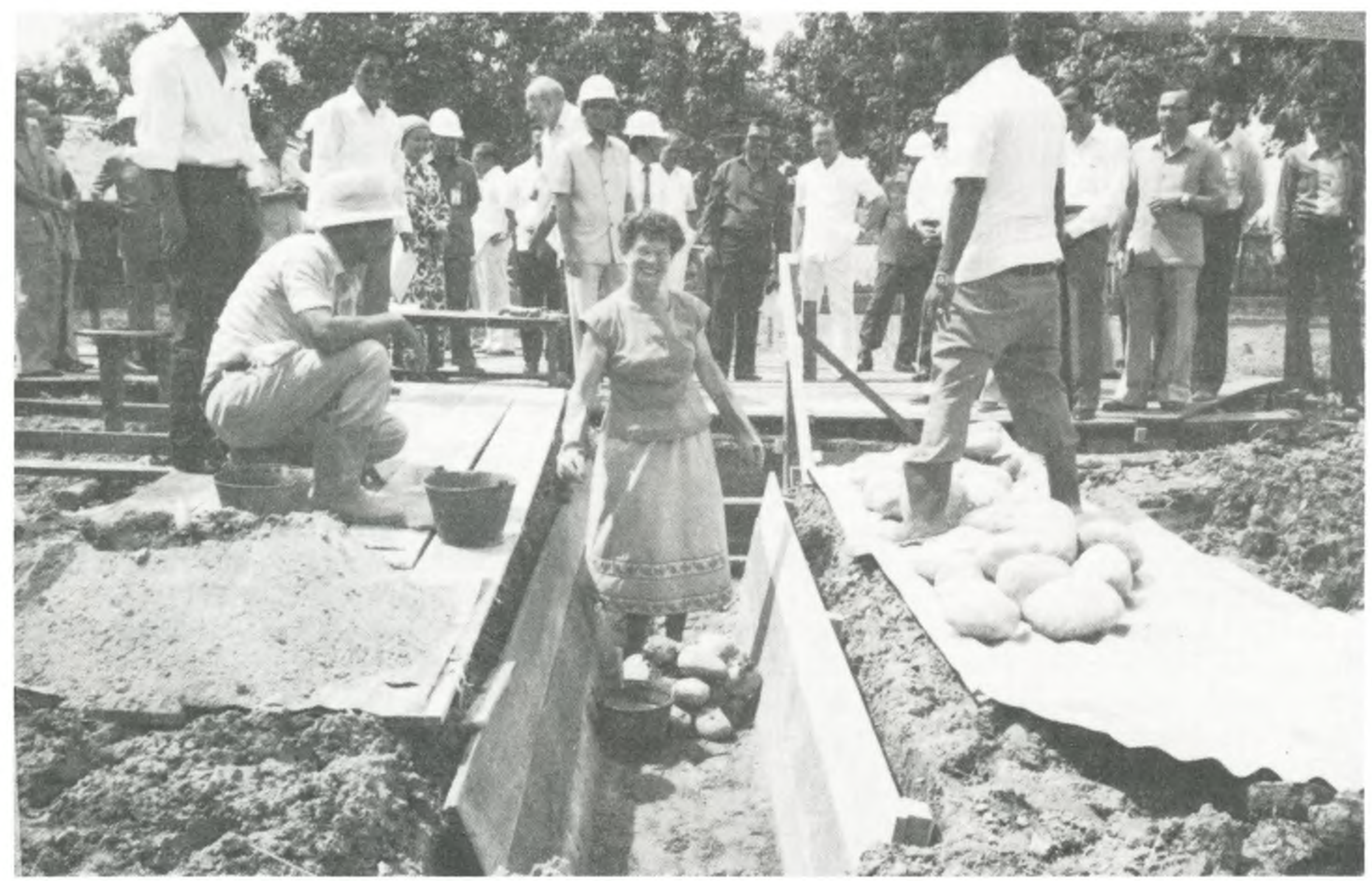

The author places the cornerstone in the foundation for the new Central Library building at the University of North Sumatra, Medan.

materials on Indonesian history, culture, socioeconomic and political development, and some information about the University of North Sumatra. I arrived on site at Medan on September 7, 1985.

Following my arrival, I established a working relationship with my counterparts Dra. Ramla Sari and Dr. Rustam Effendi. The counterparts are an important part of the consultancy. Their role is that of a vital link with the university - they provide the necessary library information in the Indonesian context. They bridge the cultural differences that are invariably present when one works in a developing country. Ultimately, the counterparts are the ones who will carry on the project when the consultant returns to the United States. Only as a team can the consultant and his counterparts be able to bring about a change in the library services at the University of North Sumatra.

The terms of reference for my consultancy prepared by university administrators and the Project Implementation Unit officers were as follows:

1. Review existing library facilities, collections, and services available at USU; review the library situation in Sumatra and elsewhere in Indonesia with an emphasis on cooperative endeavors.

2. Prepare and assist in the implementation of plans to improve the existing library system with special reference to:

a. Determining the extent of centralization and decentralization of library facilities.

b. Planning the space requirements, layout, storage, study rooms, and other requirements for the new central library building. c. Preparing lists of books and journals required, and establishing a system for regular requisitioning and ordering; establishing suitable links with publishers as well as local and foreign libraries, with a view to assisting library development.

d. Establishing suitable classification, filing, and cataloging systems; establishing the best computerized coding for these systems.

e. Establishing a suitable system to facilitate information retrieval, including copying facilities for staff and students.

f. Planning the recruitment and training of USU library staff; meeting all library staff and checking qualifications; assessing educational needs.

g. Organizing a library committee and meeting with it regularly.

\section{Review of library facilities}

The review took place at both local and national levels. I found out that at USU there were two separate library systems:

The Central Library (Perpustakaan Pusat), whose librarian reports directly to the rector. The Library's holdings are approximately 10,000 titles and over 25,000 volumes of monographic publications and 43 serial titles, none of which represent a complete run or subscription. The Central Library is staffed with 18 employees, three of whom are professional librarians.

Departmental Libraries (Perpustakaan Fakultas), consisting of nine departmental libraries that are units of faculties, which report directly to 
their respective deans. These units are independent of each other and there is no organizational link between the central and nine departmental libraries either through supervision or coordination. The total staff of departmental libraries is approximately 40 employees with collective holdings of close to 24,000 monographic titles in 95,000 volumes, and 450 serial titles.

In order to understand the general Medan library situation, I visited the Medan Public Library and the Regional Library of North Sumatra. Both visits were useful, because they gave me a broad picture of the system of provincial and public libraries in Indonesia. I also had several delightful talks with Mr. Halim Lukman, the owner of a local bookstore, Toko Buku Deli. He provided much information pertaining to the logistics of book acquisition in Indonesia.

From October 26 to November 2, my counterpart Rustam Effendi and I visited the libraries of educational colleges and universities in Padang (West Sumatra) and in Jakarta and Bogor (Java). In Jakarta, Aside from Universitas Indonesia and IKIP Jakarta, we also visited the Indonesian Institute of Science (Lembaga Ilmu Pengetahuan Indonesia) and its National Scientific Documentation Center, the National Library of Indonesia, and the Center for Library Development, Task and Functions (Pusat Pembinaan Perpustakaan Nasional).

We also held a valuable conference with Prof. Frank Hogg, consultant of the World Bank Project for the development of schools of library science in Indonesia. He recommended USU as a regional center for library education in Western Indonesia. The last meeting of our study tour was held in the home of Roger Beckman and Andrea Singer, library consultants from the Indiana University Libraries for the MUCIA/World Bank Project IX. We exchanged ideas and compared our efforts for the development of centralized library services at two different universities.

Two important points resulting from this study tour should be stressed:

- Library services at the institutions we have visited are better developed than those at USU. This means that there is a "national model" available that USU could follow in order to improve its library services. The "western model" should complement only what the Indonesian libraries have not yet achieved themselves.

- USU is isolated from the mainstream of library activities because of its geographical location. The University administration should encourage and financially help its professional librarians to become active members of the Indonesian Library Association in order to overcome its parochialism.

\section{Centralization at USU}

The evidence established during the review process supported the centralized library system:

a. The campus of USU is located at one site. b. According to the Abstract Master Plan of the Development for the North Sumatra University of 1980-1990 and its projection of physical development, the size of the Central Library will expand from 1,610 square meters (1980) to 6,090 square meters (1990) while the size of all departmental (facultas) libraries will remain unchanged.

c. The new Central Library building will be centrally located on campus and therefore easily accessible to all patrons.

d. The university administrators favor the centralization of library services-with the possible exclusion of the Law Library and the Medical Library-over the continuation of the current decentralized system.

e. Resources acquired with the Asian Development Bank loan funds are deposited and will continue to be deposited in the Central Library. Thus, the book collection of the Central Library will be significantly enlarged.

\section{The new central library building}

According to the terms of the contract, my consulting responsibilities were defined as those of a library consultant/book collection specialist. Another consulting position as a library building specialist was to be filled later. In November 1985 I was asked, however, to give comments on the blueprint for the new building. I agreed only after it was understood by all parties involved that I am not a library building specialist and therefore my comments, given from the point of view of a practicing librarian, would be general in nature and would rely heavily on the library literature.

The plan for the new central library building was approved by the Asian Development Bank in Manila on January 24, 1986. On May 21, 1986, the cornerstone ceremony took place at USU and the construction of the new central library is now underway.

\section{Establishment of a "Model Operation"}

For a library consultant who comes from the United States, the most trying situation is to be faced with the developing country's library situation. One's impulse is to reject what exists, try to change things according to what is practiced in American libraries, and then despair for not achieving the desired results. From the very beginning I tried to avoid such an attitude. I turned my initial negative impressions into a learning experience. I examined the library's work in minute detail and I soon discovered that consulting alone would not be enough. I had to be physically present at all stages of processing and work side by side with the staff in spite of the language barrier. I tried to forget how it is done at the University of Iowa. Once I understood the USU procedures I was 
able to work from within and to organize the processing of the first shipment of books purchased with ADB loan funds, an awesome task for a staff never before faced with such a large acquisition. Three thousand titles in over 7,000 volumes must have looked intimidating to library staff that had been used to processing no more than a few hundred volumes a year.

\section{Cataloging}

Since there is no book budget allocated directly to the library administration for the acquisition of library materials, the central library is not involved either in book selection or acquisition work. Processing begins with the receipt of books. The descriptive cataloging follows the International Standard Bibliographic Description (ISBD) and is generally good. The standard cataloging code, Peraturan Katalogisasi Indonesia (Jakarta, 1981), follows the international developments prescribed by IFLA. The subject system used was the 11 th edition of the Sears List of Subject Headings and the classification system is the 19th edition of the $D e$ wey Decimal Classification to which is added an appendix for specific Indonesian topics, Perluasan dan Penyesuaian Notasi untuk Beberapa Seksi dalam Dewey Decimal Classification Khusus yang Berhubungan dengan Indonesia (Jakarta, 1981).

The central library agreed to accept CIP records for cataloging, and this decision introduced the Library of Congress Subject Headings. We sent two requests for the books and were lucky to obtain an 8th edition from the U.S. Library of Congress Office in Jakarta. We were also greatly reassured by Mary K.D. Pietris's letter, in which she related to us that the two systems (Sears and LCSH) could be interfiled successfully with only $15 \%$ of the headings clashing.

Another major project was the establishment of the information dissemination system. The work on the public card catalog started in 1982. Prior to this, books were not cataloged and the retrospective cataloging of earlier holdings was not attempted due to the lack of staff. Now the catalog is fairly representative of the library's holdings and has close to 50,000 cards organized in an authortitle-subject file and a shelf list. What is also important is that we have trained staff who are eager to observe the filing rules to serve the catalog. Recently the library acquired the card catalog cabinets and for the first time made the public catalog available to the patrons.

\section{Stacks organization}

After I examined the stacks I found out that the books were out of Dewey Decimal Classification sequence in all sections; even the sections were confused and a large percentage of books did not have labels. It was obvious that if we planned to integrate the new books with the existing collection, we first had to put in order what was already there.

The work on the rearrangement of the stacks started immediately. Relabeling of unmarked books was done at the same time. Along with the rearrangement of the books, the rules for the organization and maintenance of the stacks were developed. The final marking of the stacks sections is taking place now after all new books have been

\section{I had to be physically present at all stages of}

\section{processing.}

processed and shelved.

On the whole, the "model operation" for the processing of library materials has been established successfully. It was tested on the first shipment of books bought with the ADB loan funds. The kernel of the future Central Library Processing Department exists. In the recommendations for the future development of library services at USU, we suggested computerization and networking. We offered information on software packages, hardware possibilities, and other elements relevant to computerization. For the time being, however, this is not possible because there is no infrastructure that would support such a system. First, we had to organize a manual library processing system. Once networking and computerization have developed in Indonesian libraries, the University of North Sumatra will follow the national trend in automation.

Along with the development of a model operation, we prepared recommendations regarding the organizational structure and staffing of the new central library. Our particular concern was the establishment of a strong acquisitions department and the formulation of sound collection development policies. Another important event was the appointment of the Library Committee, which will monitor the development of library services and promote the use of library resources.

In conclusion, I would like to say that sometimes I felt alone and I wished there could have been a team of library consultants. I had the support, however, of MUCIA consultants, many of whom were interested in library matters. I also turned to help to the University of Iowa Libraries. For instance, when we discovered that many new books were damaged by dampness, bookworms and rodents because of their prolonged storage in the unfavorable conditions of the humid tropical climate, the University of Iowa book conservator, William 
Anthony, immediately answered my call for help. He sent the names of chemicals, procedures to be applied, and literature on preservation. Other colleagues responded equally well and in this report I want to thank them publicly. It was good to know that the University stood by me when I was half a world away from home.

This consulting assignment has been most enlightening not only because I learned a lot about the state of librarianship in a less than ideal setting, but also because I experienced a wealth of crosscultural interactions in living among and working with my Indonesian colleagues. I learned to listen carefully to what my counterparts and other coworkers had to say, and was open to Indonesian values and their ways of doing things. I learned to be patient and not to despair when the proposed changes were not implemented as fast and as well as I wanted them. I was always aware that in our reports we must recommend solutions that will be possible in USU and Indonesian contexts. To suggest that USU should merely accept American ways of doing things and propose a simple transplant of American library services to Northern Sumatra would not work.

\title{
Wiley Dyer and the
}

\section{library as information processor}

\author{
By Sarah Barbara Watstein \\ Head, Reference Division \\ Hunter College
}

\section{The ACRL President's Program in New York last June took a fresh look at a controversial case study.}

B now, many academic librarians nationwide have been involved, directly or indirectly, in the examination of the issues surrounding the rapid introduction and integration of technology on the mythical campus known as Garfield University. Some of us participated in this examination on October 28, 1983, at a Tri-Chapter ACRL Symposium entitled "Life on the Technology Express" (see C\&RL News, January 1984, pp.9-10). Others participated in this examination on June 30, 1986, at the ACRL President's Program in New York also entitled, "Life on the Technology Express." This article focuses on the two Garfield University programs and provides some background on their development.

\section{Garfield University and its dilemmas}

Easily recognizable to most ACRL members are several of the most vocal characters and details in the controversy engulfing the Garfield University campus in suburban Clifton since the inauguration of President Wiley Dyer. At the helm of the Heathcliff Library on the Garfield University campus is Ely Berrien, director of the library for eighteen years. Other notable library personnel are Mr. A. Keen Buch, assistant director for public services, and Minnie Roebuck, head of cataloging, and chair of DEPOT, Director's Executive Panel on Technology. Other University notables are Irwin 